\title{
Paulina Wiernicka
}

Uniwersytet Łódzki

\section{Spojrzenie na muzykę w słuchowisku okiem teoretyka, praktyka, muzyka}

\author{
Muzyka jest źródłem poznania nieosiągalnego i niemożliwego do \\ przekazania u słowach. Muzyka, która pozwala przekroczyć \\ granicę naszych zuykłych zuiązków ze śuiatem, która ukazuje \\ to, co niewidzialne, udostępnia to, co niedostępne, co nieuyobra- \\ żalne... ${ }^{1}$
}

Louis Aragon

\begin{abstract}
Streszczenie
Artykuł traktuje o różnych spojrzeniach na muzykę w słuchowisku. Odmienne doświadczenia i inną wiedzę mają teoretycy, inną ilustratorzy muzyczni, a jeszcze inną muzycy biorący udział w nagraniu lub muzycy-słuchacze. Na trzy części artykułu składają się aspekty teoretyczne funkcje muzyki w słuchowisku określone przez badaczy radia, aspekty praktyczne - sprecyzowane na podstawie osobistych doświadczeń jako ilustratora muzycznego Małgorzaty Małaszko-Stasiewicz, a także spojrzenie odbiorcy-muzyka na podejmowaną tematykę muzyczną i sposoby realizacji funkcji muzyki u słuchowisku.
\end{abstract}

Słowa kluczowe: radio, audycja, słuchowisko, dźwięk, muzyka, głos, muzyk, praktyk, teoria, artystyczne formy radiowe, teatr radiouy, cisza w słuchowisku, funkcje muzyki, muzyka transcendentna i immanentna, muzyka programowa i absolutna, rola muzyki, ścieżka dźwiękowa.

\section{Looking at music in radio plays as theoretician, practician, musician}

\section{Abstract}

The article deals with different approaches to the music in the radio. Other experiences and other knowledge is that of theorists, other of illustrators of music, and other of musicians involved in the recording or musicians-listeners. Three of the parts of article consist of theoretical aspects - music features in the radio set by the researchers of radio, practical aspects - defined on the basis of personal experience of an music illustrator Małgorzata Małaszko-Stasiewicz, and also regard of recipient-musician of undertaken subject of music and ways of implementing the functions of music in the radio.

${ }_{1}$ Louis Aragon, cyt. za: J. Tuszeuski, Paradoks o słowie i dźwięku. Rozważania o sztuce radiowej, Wydawnictuo Adam Marszałek, Toruń 2002, s. 220. 
Key words: radio, broadcast, radio play, sound, music, voice, musician, practice, theory, artistic forms of radio, radio drama, silence in the radio, music features, music, transcendent and immanent, program music and absolute, role of music, soundtrack.

\section{Wprowadzenie}

Spojrzenie na muzykę w słuchowisku może mieć różne perspektywy. Ważna jest zarówno usystematyzowana wiedza na określony temat, jak i jej wykorzystywanie w praktyce czy oczywiście odbiór. Za każdym z tych haseł ukryty jest człowiek teoretyk, praktyk i muzyk - przedstawiciele grup ludzi radia, a w tym przypadku słuchowiska, które to grupy żyją ze sobą w symbiozie, korzystając ze zdobytych doświadczeń, dorobku artystycznego i wrażeń publiczności po każdym wysłuchanym przedstawieniu audialnym. Zrozumieniu złożoności zjawiska muzyki w słuchowisku może służyć przyjrzenie się każdemu z uymienionych punktów widzenia.

\section{Charakterystyka radia jako medium}

Trudno jest mówić o muzyce w słuchowisku w oderwaniu od ustalenia, choćby najbardziej ogólnego, a mianowicie co ów termin oznacza i jak jest współcześnie rozumiany.

Podobnie trudno, czy wręcz nie sposób, analizować słuchowiska jako elementu, gatunku sztuki radiowej, nie nakreśliuszy choćby najbardziej pobieżnej charakterystyki radia jako medium. Wiele cech uszystkich gatunków radiouych, a szczególnie gatunków artystycznych, w tym słuchowiska, determinują szanse, możliwości, ale także ograniczenia, które niesie za sobą to konkretne medium. Jednakże szczególnie ważna jest jego misja i dostępność: „Radio umieściło suój mikrofon przed ustami zarówno polityka, jak i profesora, kaznodziei i poety, dziennikarza i nawet człowieka ulicy. Ono pyta, interweniuje, budzi uśpionych, potrząsa nieśmiałymi”2.

Mówi się o audytywności i audialności radia. Z francuskiego auditif znaczy „przyswajany, przyjmowany za pomocą słuchu”, audialny natomiast to „taki, który odnosi się do słuchu, działa na słuch, jest odbierany słuchem"4. W radiu, w przeciwieństuie do telewizji, nie mamy dostępu do obrazu, który dookreśla w znacznym stopniu intencje autora. Wówczas odbiorca w niewielkiej, jak pokazują wyniki badań, części interpretuje przekaz przez odczytywanie merytorycznych treści, skupiając swoją uwagę na elementach pozawerbalnych: postawie, mimice twarzy, gestykulacji, odległości. W przypadku radia na sto procent odczuć słuchacza składa się uyłącznie to, co usłyszy. Nie ma możliwości domyślenia się w inny sposób, o co tak napraudę chodziło

2 Ibidem, s. 27.

3 H. Zgółkowa, Praktyczny słownik wspótczesnej polszczyzny, t. 1, Wydawnictuo Kurpisz, Poznań 1994, s. 44.

4 Ibidem, s. 39. 
nadawcy. Tę cechę, określaną mianem awizualności, szeroko prezentował na przykład Michał Kaziów w swojej rozprawie - $O$ dziele radiowym - z zagadnień estetyki oryginalnego stuchowiska, nazywając radio medium niewidomym ${ }^{5}$.

To właśnie owa awizualność nakłada na spikerów, prezenterów, wreszcie aktorów obowiązek jasnego formułowania komunikatów i uyraźnego artykułowania emocji, a na słuchaczy z kolei - konieczność skupienia swojej uwagi, jeśli akurat w tym określonym momencie radio nie jest dla nich wyłącznie głosem w tle. Jako że rzadko, niestety, słuchamy radia, a zazwyczaj po prostu je słyszymy, przylgnęło do niego również określenie „medium towarzyszącego”. Niekoniecznie trzeba tutaj uskazywać na pejoratywność tego stuierdzenia, gdyż jak podaje fragment Radio gada z 1973 roku, opublikowany w 4 numerze „Odry”:

Doszło do tego, że radio gra i gada [...] podczas śniadania, domowej krzątaniny, przy rozmowie, przy odpoczynku, zabawie, a także twórczej pracy. Gra, gada, bo nie przeszkadza! Czasem fala muzyki jest tak natrętna, że musimy ją [... przekrzykiwać, żeby nas usłyszano. Radia jednak nie gasimy. Jest nam potrzebne. Nauet do łazienki bierzemy ze sobą tranzystorek. Albo jak pływamy samotnie kajakiem szlakiem Wielkich Jezior... A może już nie potrafimy żyć bez hałasu tła?

Widzimy więc, jak ważne może być radio, obseruując jego bycie „obok nas” w codziennym życiu. Może zaciekawić nas w dowolnym momencie albo po prostu sprawić, że czujemy się mniej samotni, ale zausze jest gdzieś blisko. Poza tym, to my sami decydujemy, kiedy go słuchamy. Obecnie, u dobie uszelkiego rodzaju przenośnych odtwarzaczy i telefonów komórkowych z najnowocześniejszymi technikami, radio jest także medium bardzo mobilnym. Możemy mieć je $u$ domu, lecz również w samochodzie, autobusie czy w drodze na drugi koniec świata.

Ciekawą teorię związaną z odbiorem mediów opublikował Marshall McLuhan w dziele Zrozumieć media ${ }^{7}$. Dzieli on media na tzw. zimne i gorące, przyjmując za kryterium stopień zaangażowania poszczególnych zmysłów. Według tej klasyfikacji radio możemy przypisać do drugiej z wyodrębnionych grup, bowiem do procesu słuchania i przyswajania informacji wykorzystuje jeden zmysł - słuch, silnie go natomiast pobudzając.

Biorąc pod uwagę liczebność słuchaczy i sposób nadawania, można mówić o masowości przekazu radiowego. Co prawda komunikat jest zuykle jednostronny, ale ma właściwość docierania do szerokich mas, do wielu odbiorców. Obok tej tezy, paradoksalnie, uskazuje się również często na taką cechę jak intymność radia. Można ją rozumieć dwojako. Po pierusze, jako spotkanie nadawcy i odbiorcy, jako pewnego

5 M. Kaziów, O dziele radiowym - z zagadnień estetyki oryginalnego słuchowiska, Zakład Narodowy im. Ossolińskich, Wrocław 1973.

${ }^{6}$ Cyt. za J. Tuszeuski, op. cit., s. 34.

7 M. McLuhan, Zrozumieć media. Przedłużenia człowieka, tłum. N. Szczucka, Wydawnictua Naukowo-Techniczne, Warszawa 2004, s. 55-68. 
rodzaju rozmowę albo rozmowę $\mathrm{w}$ rzeczywistym rozumieniu tego słowa, gdy mówimy o programach, w których słuchacze dzwonią do studia, tzw. call-in. Po drugie natomiast, gdy zwracamy szczególną uwagę na ciepły, przyjemny głos wydobywający się z głośnika, jako spotkanie $\mathrm{w}$ domowym zaciszu, naturalnym i bezpiecznym środowisku każdego z nas. Czynnikiem dodatkowo wzmacniającym taki kontakt jest tzw. czasowa uspółobecność nadawcy i odbiorcy, co znaczy, że każdy z nich w tym samym momencie kieruje swoją uwagę na tę drugą stronę, odbiorca ku nadawcy, nadawca ku odbiorcy.

Cechą, która wiąże się bezpośrednio z poprzednią, jest ulotność przekazu radiowego. Coś, co u tej sekundzie mówię, w okamgnieniu jest słyszalne dla mas przed radioodbiornikami i już za chwilę staje się nieaktualne, jest już przeszłością. Przekazu nie da się zatrzymać, zapisać, powtórzyć, odebrać jeszcze raz bez sięgnięcia do Internetu, a i z jego pomocą także nie zawsze jest to możliwe, gdyż nie sposób całego przekazu udostępniać u formie plików internautom. Chuila, moment, tu i teraz są więc dla radia bardzo ważne. Niemniej jednak uskazać należy na istotny fakt uystępowania procesu konwergencji mediów. Konwergencja, czyli swoiste przenikanie i uzupełnianie się mediów, w tym przypadku przejawia się w relacji radio-Internet. Bardzo prawdopodobne, że w niszouych dziedzinach sztuki, do których należy słuchowisko w dzisiejszych czasach, ta uspółpraca jest podwójnie ważna. Już na poziomie informacji o dostępności interesującego nas spektaklu radiowego czy godziny jego wyemitowania na antenie, proces ten jest bardzo widoczny. Ponadto uspółcześnie stacje radioue posiadają swoje profile na Facebooku i tam umieszczają zapowiedzi wielu audycji, przypominając lub niejednokrotnie informując o swojej ofercie.

Jednym z dóbr sztuki radiowej jest słuchowisko, którym zajmuje się u swojej pracy. Realizując rozmaite funkcje, zawiera w sobie uszystkie wymienione już elementy, na nich się opiera i z nich korzysta. Współtuorzy artystyczną stronę radia, zapraszając słuchaczy do chwili refleksji, wytchnienia, rozrywki.

\section{Charakłerystyka słuchowiska jako audialnej formy artystycznej}

Czym ułaściwie jest słuchowisko? Laik po wysłuchaniu tej formy określiłby ją jako historię nieprawdziwą, fikcję literacką, z którą zapoznają nas uczestniczący aktorzy lub narrator, przeznaczoną do wykonania audialnego. Właściwie nie byłoby w takiej wypowiedzi błędu. Stownik terminologii medialnej Walerego Pisarka podaje, że

słuchowisko to inaczej dramat radiouy, gatunek z pogranicza, bywa radiową adaptacją utworu scenicznego lub opiera się na tekście oryginalnym, dopuszcza wielość konwencji i stylów. Odrzucając rygory dramatu scenicznego, podporządkouuje się wymogom formalnym produktu przeznaczonego do emisji radiouej (skrótowość, przejrzysta kompozy- 
cja, rytm scen, połączenie elementów reportażouych i literackich, indywidualizacja językowa postaci) $)^{8}$.

Jest to niewątpliwie bardzo syntetyczna i jasna definicja, odpowiednia do zgłębienia podstawowej wiedzy o gatunkach radiowych, jednak do dokładnego zbadania ciekawej materii słuchowiska wydaje się niewystarczająca. Złożoność i wieloznaczność składowych całego przedstawienia radiowego są tak intensywne, że nie sposób omówić je w dwóch zdaniach.

„Na początku było Słowo" - i ja również od niego rozpocznę suoje rozuażania. Grecki sofista Gorgiasz z Leontinoj, w Pochwale Heleny powiada:

Słouo (logos) jest wielkim mocarzem, który najmniejszym ciałem i najskrytszą siłą cudóu dokonywa, zdoła bowiem i trwogę odpędzić, i troskę usunąć, i radość sprawić, i odwagę powiększyć [...]. Opanouuje uwagę słuchaczów, sprawia ono, że nawet to, co się nie zdaje, zdaje im się ${ }^{9}$.

Od wynalezienia mowy, przez przekazy z ust do ust, Gutenbergouskie czcionki i druk, mikrofon i głośnik radiowy aż do „wtórnej oralności”, o której mówił Walter Jackson Ong $^{10}$, słowo towarzyszy nam przez cały czas. Słowa pomagały pierwotnym ludom się komunikować, żołnierzom przekazywać rozkazy i komunikaty na froncie, mieszkańcom całego świata, dzięki wynalazkom, dowiadywać się o ważnych wydarzeniach i to właśnie słowo i dźwięk stały się podstawą do eksperymentowania $\mathrm{w}$ dziedzinie radiofonii, pełniąc funkcje nie tylko informacyjne i wychowawcze, ale także, rekreacyjne, komercyjne i rozrywkowe. Radio nadaje słowu drugi, głębszy sens, stawia je w centrum uwagi, utrzymuje na piedestale od wielu lat oraz pozwala na jego rozkwit i przeobrażenia, niosąc tym samym ogromny ładunek emocjonalny w kierunku słuchaczy. Słowo w radiu nie jest wyimaginowanym tworem, stanowi część natury ludzkiej. Pozwala na odkrywanie tego co nieznane, w głośnikach radioodbiorników tysięcy słuchaczy łączy ich mimowolnie, pełniąc funkcję integracyjną.

Jednakże czym byłoby słowo bez głosu, chyba nie miałoby szansy zaistnienia, a na pewno nie $w$ formie mówionej. Tutaj niejako podsumouując omówienie słowa i zapowiadając kolejny element składowy słuchowiska, przytoczę sformułowanie uybitnej badaczki słuchowiska Joanny Bachury-Wojtasik ${ }^{11}$ :

8 W. Pisarek, Stownik terminologii medialnej, Touarzystwo Autorów i Wydawców Prac Naukouych Universitas, Kraków 2006, s. 198.

9 Cyt. ze ustępu Tadeusza Sinki do Trzech poetyk klasycznych: Arystoteles, Horacy, Pseudo-Longinos, tłum. T. Sinko, Zakład Narodowy im. Ossolińskich, Wrocław 1951.

10 W.J. Ong, Oralność i piśmienność. Stowo poddane technologii, tłum, ustęp i red. nauk. J. Japola, wyd. II popr., Wydaunictua Uniwersytetu Warszauskiego, Warszawa 2011.

11 J. Bachura-Wojtasik, Analiza semiologiczna współczesnego słuchowiska, „Acta Uniwersitatis Lodziensis. Folia Literraria Polonica" 2010, t. 13, s. 484. 
Teatr radiouy składa się z dwóch rodzajów znaków, tj. znaków językouych i niejęzykowych. Z pewnością nie mógłby on istnieć bez jednego z najistotniejszych elementów komplementarnych - słowa. Po pierusze, słowo tworzy językouy komunikat, a więc zawiera u sobie znak językowy; po drugie, komunikat ów ma swój własny akustyczny materiał ekspresji, na który składa się głos, rytm mówienia, intonacja, akcent, wysokość, barwa, szybkość mówienia. Praktyka radiowego teatru pokazuje, że myśl, słowo w radiu nie istnieje bez głosu aktora. [...] Óu głos moglibyśmy poróunać do ciała u teatrze scenicznym, do ciała, które chce żyć, być aktywne, mówić, uzruszać, zachwycać.

Sam głos jednak nie jest wartością bezuzględną. Jego bytność ma sens utedy, gdy funkcjonuje ze słowem lub innym dźwiękiem. Jego współpraca ze słowem uskazuje na treść i przekaz, natomiast głos jako nośnik dla różnego rodzaju dźuięków pozuala dookreślić charakter, nastrój, wiek czy samopoczucie bohatera. Funkcje głosu, które uymieniają Joanna Bachura-Wojtasik i Aleksandra Pawlik, to: indywidualizacja postaci uwzględniająca takie szczegóły jak wiek, wykształcenie czy samopoczucie, dookreślanie charakteru przestrzeni, uspółkształtowanie czasu, wzbogacanie sytuacji dramatycznej, wzmacnianie siły słowa itd. Funkcją niezwykle istotną, z punktu widzenia powodzenia lub porażki słuchowiska, jest uwiarygodnienie przekazu ${ }^{12}$. Głos mówiący „mamo, czy mogę iść na plac zabaw?” powinien być wysoki, delikatny, może nie do końca dokładny i przejrzysty, by słuchacz uwierzył w jego przynależność do dziecka. Podczas przygotowań do akademii szkolnych panie wielokrotnie zuracają uczniom uwagę, by wkładali w swoją recytację trochę serca, gdyż „odklepany” tekst nikogo ani nie zainteresuje, ani tym bardziej nie poruszy. Krzyk musi być uykrzyczany, szloch wypłakany, a radość roześmiana, inaczej próżny trud. Najlepszy nawet tekst nie będzie przyjęty z aprobatą, ponieważ nie będzie prawdziuy.

Podkreślaniu uszelkiego rodzaju emocji służy w formach artystycznych muzyka, której poświęcam tę rozprawę. Dla materii słuchowiska współtowarzyszenie słowa i muzyki jest bardzo ważne. Tekst, słowo są z natury rzeczy amuzyczne, mają swój rytm i intonację, jednak dźwięki zagrane czy zaśpiewane mają większą moc jednokrotnego przekazywania wielu znaczeń i urażeń estetycznych zarazem. Tadeusz Kwiatkouski pisał:

Elementy jak poutarzanie, kontrast, rytmika są tak samo właściwością literacką, jak i muzyczną. Można by mówić o muzycznej konstrukcji dzieła, gdyby istotne cechy struktury muzycznej, a więc jednoczesny rozwój kilku odrębnych samodzielnych płaszczyzn formalnych (polifonia, harmonia), czy instrumentalnych dało się uprowadzić u materiał literacki. Niestety u technice literackiej są to środki nie-osiągalne ${ }^{13}$.

12 J. Bachura, A. Pawlik, Stuchowisko i jego „anatomia” [w:] E. Pleszkun-Olejniczakowa, J. Bachura, A. Pawlik, Dwa teatry. Studia z zakresu teorii i interpretacji sztuki stuchowiskowej, Wydawnictuo Adam Marszałek, Toruń 2011, s. 165.

13 T. Kuiatkouski, Muzyka w literaturze współczesnej, „Ruch Muzyczny” 1948, nr 8, s. 3. 
Muzyka, która bez słuchowiska, sama u sobie stanowi wielką wartość, u nim otrzymuje dodatkouy sens, róunocześnie niejako nadając go słouu. Narzuca słuchaczowi skojarzenia i już po pierwszych dźwiękach pozwala zakwalifikować audycję do nostalgicznych, wesołych, strasznych czy groteskowych. Umożliwia wprowadzenie nowego bohatera, powrót do wydarzeń z przeszłości, zawiązanie akcji czy rozwiązanie konfliktu. Ma w sobie ponadprzeciętną moc w kreowaniu obrazu słuchowiska i odczuć artystycznych odbiorcy. Ponieważ muzyka w słuchowisku stanowi przedmiot moich badań, poświęcę jej osobny fragment u dalszej części pracy.

„Od muzyki piękniejsza jest tylko cisza" - mawiał francuski pisarz i dyplomata Paul Claudel. Sentencja ta może uydawać się banalnym frazesem, jednak w odniesieniu do natury słuchowiska zapewne niejednokrotnie się sprawdziła. Muzyka może wyrazić coś, czego nie wyrażą słowa - to prawda. Cisza natomiast bywa jeszcze bardziej pożądana, jeśli oczywiście nie jest zbyt długa, gdyż tylko ona może wzbudzić takie poruszenie, którego nie zdołają wyrazić ani słowa, ani muzyka. To z niej każdy dźwięk „wyrasta” i u nią „wpada”. To cisza odpowiada na pytania, do których odpowiedzi często nie chcemy słyszeć, do których odpowiedź nie jest potrzebna. Wówczas cisza „mówi” o wiele więcej. To ona jest tą chwilą napięcia, gdy czekamy aż spektakl radiowy się rozpocznie i to ona ten spektakl kończy. Podobnie jak w kościele, gdy ksiądz po kazaniu daje chuilę suojemu audytorium na przemyślenie, daje czas słouru na uybrzmienie, tak samo u radiu cisza jest potrzebna dźwiękowi. Nadaje mu sens wtedy, gdy on sam już się skończy. Dobry przekaz słowny czy muzyczny może sprawić, że podczas ciszy wieńczącej całe dzieło poczujemy dreszcz emocji, wzruszenie, zachuyt, niedosyt. W słuchowisku cisza, podobnie jak muzyka, ma określone funkcje: zawiesza akcję, pozwala scharakteryzować postać, dodaje ekspresji i dramaturgii, tworzy czas, kieruje wrażenia słuchacza na określone obszary.

Gest foniczny, czy też inaczej mówiąc, dźwiękouy ruch mimiczny, oddaje to, czego nie są u stanie przekazać słowa. Może występować niezależnie od słowa, w jego sąsiedztwie lub podczas jego trwania. Pełni funkcję dopowiadającą, wyprzedzającą słowo, wzmacniającą treść. Zachowania awerbalne nie są zbędne czy niezauważalne w słuchowisku, przeciunie, różne ich rodzaje podkreślają u różny sposób intencje autora. Istnieją tzw. gesty interpunkcyjne, uprowadzające pauzy, niezleksykalizowane gesty foniczne, takie jak westchnienia, jęki, krzyki, silniejsze wdechy, wyraźnie słyszalne przyspieszenia oddechu, a także wspomniane chrząknięcia ${ }^{14}$, intrawerbalne gesty foniczne - silnie zuiązane ze słowem, będące pewnym jego przeobrażeniem czy dźwięcznym uypaczeniem jak choćby przedłużenie głoski czy sylaby. Dla gestu fonicznego ważne jest pojęcie intonacji, Joanna Bachura i Anita Paulik z Łódzkiej Szkoły Radioznawczej zauważają, że „intonacja nadaje właściwe znaczenie gestowi fonicznemu, nie dopuszczając do błędnej interpretacji wieloznacznych wyrazów

14 J. Bachura, A. Pawlik, Stuchowisko i jego „anatomia”, op. cit., s. 160. 
wykrzyknikowych" ${ }^{15}$. Widzimy zatem, jak ważną rolę pełni gest foniczny w procesie interpretacyjnym. Sława Bardijewska o kuchni akustycznej pisze:

Materiał akustyczny wzbogaca tworzywo dzieła radiowego o odgłosy, dźwięki naturalne, sygnały zuiązane z osobami, przedmiotami, zjawiskami przyrody. Są one nośnikami znaczeń przeniesionych z rzeczywistości pozaartystycznej, poszerzanych o funkcje [...] są radiowym odpowiednikiem wizualności, tworzą widzialność wyobrażoną - unaoczniają sytuacje, osoby, przedmioty przedstawione fonicznie ${ }^{16}$.

Wnioskować można, że efekty akustyczne są swoistymi oczami w słuchowisku. To dzięki nim słuchacz może przenieść się w określone miejsce. To one tworzą jakby trójuymiarowy charakter przedstawienia radiowego. Przenoszą odbiorcę na plażę dzięki szumowi fal morskich, na łąkę, pola podczas żniw czy zimową zawieruchę. Wydawać by się mogło, że odgłosy natury nie są trudnym do wykreowania efektem. Pamiętajmy jednak, że nasze ucho dobrze zna tego typu dźwięki, tym trudniej może być twórcom osiągnąć upragniony, a przede wszystkim wiarygodny efekt. Poza tym należy mieć na uwadze to, jak dźwięk musi być oczywisty, czysty i jasny, by nie osiągnąć mimowolnie szumu komunikacyjnego, a tym samym nie wprowadzić słuchacza u błąd. Takie bowiem pomyłki mogą okazać się rzeczowe dla interpretacji i oceny danego spektaklu radiowego.

Bardijewska zuraca także uwagę na dramaturgiczną, a co za tym idzie formotwórczą funkcję efektów akustycznych. Dzięki konkretnym dźwiękom rozpoznajemy emocje towarzyszące bohaterom, na przykład trzaśnięcie drzwiami może oznaczać złość czy nawet wściekłość bohatera. Ów zabieg wsparty warstwą słowną będzie oczywistym sygnałem dla odbiorcy. W takim momencie sielankowy dotąd charakter rozmowy w słuchowisku może przeistoczyć się w kłótnię, co będzie stanowić główną oś fabuły. Słowa, nawet te najlepiej dobrane, nigdy nie dadzą takiego efektu, jak odpowiednio zaprezentowany efekt dźwiękowy. Mówienie o tym, że ktoś szedł posuwistym, ciężkim krokiem po starych, drewnianych schodach, budząc przy tym niepokój Kasi, która ze strachu schowała się pod łóżko, jest pozbawione sensu. Dźwięk daje takie możliwości i takie wrażenia, że odbiorca, słysząc go, sam odczuwa ów niepokój, utożsamiając się niejako z bohaterką i czekając na rozwiązanie tej napiętej sytuacji. O tym, jak istotną rzeczą, także dla twórcy, jest zaproponowanie słuchaczowi wiarygodnego i być może niezapomnianego przekazu mówi reżyser filmowy i radiouy Maciej Drygas:

Bardzo ważne dla mnie było, żeby słuchacz, podążając za tą historią, włączył uyobraźnię i poleciał uspólnie z astronautami u kosmos, pobył tam i wrócił na Ziemię. Myśląc o scenografii dźwiękowej, czułem, że momentem kluczouym rozpoczynającym tę podróż powinien być uyrazisty, energetyczny start rakiety. Szukałem takich efektóu w archiuum

15 Ibidem, s. 159.

16 S. Bardijewska, Nagie słowo. Rzecz o stuchowisku, Dom Wydawniczy Elipsa, Warszawa 2001, s. 59. 
kosmicznym u Moskwie, ale wszystkie były jakieś blade, matowe, nagrane z dużej odległości. Przesłuchałem również liczne nagrania wykorzystane w amerykańskich filmach science fiction. Te brzmiały zdecydowanie lepiej, jednak, jak na moje ucho, były zbyt plastikowe, czuło się, że są wygenerowane przez syntezatory. Wspólnie z realizatorem dźwięku Andrzejem Brzoską postanowiliśmy sami złożyć taki efekt, uykorzystując do jego budowy wyłącznie dźwięki dokumentalne. Szkieletem był start rakiety Sojuz, który wzmocniliśmy między innymi rykiem silników przelatującego odrzutouca, hukiem płomienia uypluwanego przez palnik u balonie, a nawet uybuchami granatów. Pracowaliśmy na kilkunastu ścieżkach dźwiękouych przez cały dzień. Skomponowany przez nas efekt startującej rakiety został zdeponowany $\mathrm{w}$ archiuum Teatru Polskiego Radia i do dzisiaj może być wykorzystywany przez innych radiouców ${ }^{17}$.

Tak przygotowany dźwięk zasilił tzw. efektotekę, z której zasobów mogą korzystać twórcy. Przytoczony fragment pokazuje, że gdy coś zaistnieje u głowie miłośnika sztuki radiowej, jest to możliue róunież do osiągnięcia realnie, by każdy słuchacz miał szansę na odbycie wielu podróży, w najdalsze zakątki świata bez wychodzenia z domu.

\section{Teoretyczne spojrzenie na muzykę w słuchowisku}

Wiesław Myśliuski u swoim utworze Traktat o łuskaniu fasoli ${ }^{18}$, na podstawie którego nagrano słuchowisko Wybierz saksofon ${ }^{19}$, pisał następująco: „Gdy słowa już daremne, myśli daremne, a uyobraźni nie chce się już uyobrażać, [została] jeszcze tylko muzyka. Jeszcze tylko muzyka na ten świat, na to życie”. Nie ignorując więc pozostałych z materii słuchowiska, ją właśnie zbadam najdokładniej. Zresztą, zgodnie z tym, co mówiła na swoim wykładzie Dyrektor II Programu Polskiego Radia i jednocześnie znakomity oprawca muzyczny - Małgorzata Małaszko-Stasiewicz, w odniesieniu do działalności artystycznej, jaką jest słuchowisko: „nie ma możliwości pełnego obiektywizmu”. Muzyka cechuje się niebagatelną mocą oddziaływania na człowieka, „posiada ona zdolność przekazywania wielu różnorodnych emocji i treści, przy czym wyjątkowość muzyki wynika z jej uniwersalności, a jednocześnie nieprzekładalności na żaden inny język" ${ }^{20}$. Jeżeli więc już w autonomicznej postaci ma takie ułaściwości, jakie może być jej znaczenie i odbiór u połączeniu z treścią słuchowiska? Mówiąc najoględniej - na pewno bardzo istotne.

O funkcjach muzyki pisały przedstawicielki Łódzkiej Szkoły Radioznawczej, między innymi Aleksandra Pawlik i Joanna Bachura w artykule zatytułowanym Znaczeniowa funkcja muzyki $w$ słuchowisku. Ich zdaniem muzyka w połączeniu ze słowem,

17 M. Drygas, Wyzwolić wyobraźnię, dokument radiowy [w:] Biblia dziennikarstwa, red. A. Skwosz, A. Niziołek, Społeczny Instytut Wydawniczy, Kraków 2010, s. 316.

18 W. Myśliuski, Traktat o tuskaniu fasoli, Społeczny Instytut Wydawniczy Znak, Kraków 2007.

19 Wybierz saksofon, reż. A. Piszczatouski, muz. M. Małaszko-Stasiewicz.

20 Anthony Storr, podaję za: P. Czarnek, K. Klimczak, Rola muzyki we współczesnym reportażu radiowym, „Acta Universitatis Lodziensis. Folia Litteraria Polonica” 2012, t. 17, nr 3, s. 172. 
kuchnią akustyczną i uszystkimi składnikami słuchowiska pozwala uzyskać efekt zamierzony przez reżysera, a także zrozumieć pełny sens dzieła. „Należy pamiętać, że muzyki w słuchowisku nie powinno się rozpatrywać jako jednostki samodzielnej znaczeniowo, lecz współtworzącej znaczenia wraz z innymi elementami dźwiękouymi. Słuchowisko jest więc swoistą polifonią znaczeń i brzmień”"1. Zakładając użycie w słuchowisku utworu z tekstem, funkcjonującego jako powszechnie znana piosenka, przywołane stwierdzenie wydaje się zasadne. Piosenka bowiem może pociągać za sobą pewien sens i swoistą metaforykę, jednak w połączeniu z fabułą słuchowiska będzie rozpatrywana zupełnie inaczej. Taka sama sytuacja zaistnieje $\mathrm{w}$ przypadku użycia muzyki czysto instrumentalnej. Już sam tytuł dzieła czy epoka, w której poustało, nasuną melomanowi różnego rodzaju skojarzenia. Także charakter utworu, grający instrument lub kompozytor będą odgrywać tutaj znaczącą funkcję. Dlatego tak ważna jest świadomość płynących znaczeń muzyki i słowa, świadomość właściwego ich używania.

W zakresie tej śuiadomości nasuwa się też myśl związana z wyobrażeniem autora o wiedzy odbiorcy. To oczywiste, że twórca nie jest u stanie precyzyjnie przewidzieć, z czym konkretny utwór skojarzy się setkom słuchaczy, jednak istnieje ryzyko, że konteksty przez tenże utwór przywoływane uniemożliwią taki odbiór, jaki zakładał nadawca. Sens wówczas ewokowany może być zupełnie inny albo po prostu dodatkowy, pasujący lub nie, kompatybilny lub pozostający w konflikcie z zamierzonym.

Problematykę tę poruszyła też Karolina Albińska, pisząc:

[...] do odszyfrowania warstuy dźwiękowo-muzycznej niezbędna jest chociażby wiedza na temat pochodzenia śpiewanej u słuchowisku Jak pięknie było rzucać ptytami chodnikowymi pieśni We Shall Overcome, która od dawna jest protest songiem walczących u różnych krajach manifestantów. Dopiero uświadamiając sobie, że pieśń ta weszła do repertuaru tak uznanych tuórców jak Peter Seeger, Joan Baez, Diana Ross czy Bruce Springsteen i wiedząc, że słowa «We Shall Overcome» stały się hasłem przewodnim m.in. słynnej mouy Martina Luthera Kinga, odbiorca ma szansę docenić kunszt scenariusza napisanego przez Marka Modzelewskiego oraz przemyślaną warstwę dźwiękową, pozwalającą odzwierciedlić realia toczących się $\mathrm{w}$ ramach spektaklu wydarzeñ ${ }^{22}$.

Jak widać, można uskazywać nie tylko na wiedzę o wiedzy odbiorcy, ale także na wiedzę o jego niewiedzy. W obu przypadkach końcowe interpretacje mogą się okazać bardzo różne.

Jest to, w moim przekonaniu, jednocześnie wadą i zaletą. Wadą z oczywistych uzględów - nadawca uszak chce zostać dobrze zrozumiany; zaletą zaś, bowiem jeśli

21 J. Bachura, A. Pawlik, Znaczeniowa funkcja muzyki w słuchowisku, „Acta Uniwersitatis Lodziensis. Folia Litteraria Polonica" 2012, nr 3, s. 162.

${ }^{22}$ K. Albińska, Jaskółka zwiastująca wiosnę czy relikt przeszłości? Z badań nad atrakcyjnością stuchowiska radiowego. „Acta Uniwersitatis Lodziensis. Folia Litteraria Polonica” 2011, t. 14 , s. 100. 
umieszczamy słuchowisko $w$ ramach szeroko rozumianego pojęcia sztuki, musimy przyjąć, że ma ona służyć ludziom i może być przez nich różnie interpretowana.

We uspomnianym już artykule Joanna Bachura i Aleksandra Paulik przytaczają tezę Sławy Bardijewskiej, która twierdzi, że podstawową funkcją muzyki w słuchowisku jest funkcja dramaturgiczna ${ }^{23}$ przejawiająca się $w$ oddziaływaniu na ukształtowanie linii przebiegu konfliktu, dookreślaniu napięć wewnętrznych w słuchowisku, ewokowaniu określonych emocji u odbiorcy. Inną funkcją, występującą przykładowo w słuchowisku Szczęśliwy dom wyreżyserowanym przez Andrzeja Piszczatouskie$\mathrm{go}^{24}$, jest funkcja ilustracyjna podzielona przez badaczki na figurującą jako klimat i jako tło. Wówczas scena niosąca określoną treść uraz z muzyką, uzupełniają się niejako, istnieją zgodnie obok siebie, tworząc uspólny sens, podkreślając odmienność charakteru poszczególnych scen, a także przygotowując odpowiedni nastróji ${ }^{25}$. Jako słuchacz uważam takie zastosowanie muzyki za jedno z najważniejszych, jeśli nie najważniejsze, bowiem u ten sposób twórcy ułatuiają zrozumienie założonego przekazu, przybliżają słuchowisko do ludzi. Często u takim przypadku muzyka może coś dopowiedzieć, rozwiać wątpliwości, skierować uwagę odbiorców na jednoznaczne, jasno określone przeżywanie i wnioskowanie.

Wracając do funkcji muzyki, może ona także pełnić funkcję klamry kompozycyjnej $^{26}$, czyli rozpoczynać i kończyć przedstawienie radiowe, stanowić wprowadzenie dla treści właściwej i być odprężeniem po jej zakończeniu. W takim przypadku mamy do czynienia z użyciem tego samego fragmentu muzycznego w charakterze ramy.

Szerszymi pojęciowo terminami są muzyka immanentna i transcendentna, w których opisane przeze mnie funkcje się zawierają.

Muzyka immanentna, to taka, która wynika z akcji utworu, naturalnie wpisuje się w jej fabułę. „Możliwości muzyki immanentnej częściowo pokrywają się z możliwościami muzyki transcendentnej, z tym jednak że w przypadku tej pieruszej źródło muzyki musi być słuchaczowi znane"”27. Najważniejsze jest jednak to, że rozbrzmiewająca w słuchowisku muzyka podnosi wydatnie stopień uspółuczestnictwa odbiorcy: „wyrywa” słuchacza z biernej postawy i angażuje w audialnie przedstawioną historię ${ }^{28}$. Tego rodzaju muzyka używana jest najczęściej w słuchowiskach o tematyce muzycznej jak choćby Saksofon basowy ${ }^{29}$ czy Kolacja na cztery ręce $e^{30}$, ale nie tylko w nich.

23 S. Bardijeuska, op. cit., s. 58-59.

${ }^{24}$ Szczęśliwy dom, reż. A. Piszczatouski, muz. M. Małaszko-Stasiewicz.

25 J. Bachura, A. Pawlik, Znaczeniowa funkcja muzyki w słuchowisku, op. cit. s. 164.

26 Ibidem, s. 164.

27 O muzyce immanentnej zob. J. Płażeuski, Język filmu. Książka i Wiedza, Warszawa 2008,

s. 341-352, za: J. Bachura, A. Pawlik, Znaczeniowa funkcja muzyki w stuchowisku, op. cit.,

s. 163.

28 J. Bachura, A. Pawlik, Stuchowisko i jego anatomia, op. cit., s. 173.

29 Saksofon basowy, reż. A. Piszczatouski, muz. M. Małaszko-Stasiewicz.

${ }^{30}$ Kolacja na cztery ręce, reż. J. Kukuła, muz. M. Szałkouski. 
W opozycji do tego rodzaju muzyki stoi muzyka transcendentna, stanowiąca „element struktury całego dzieła audialnego, gdy brak bezpośredniej zależności wobec śuiata przedstawionego" 31 . Tutaj muzyka nie uynika z toku uydarzeń, a jej źródło nie jest znane słuchaczom. Często stanowi funkcję przygotowującą do odbioru dzieła, rolę tła czy też łącznika dla poszczególnych scen. Ten typ słuchowisk, przeważający wśród wszystkich reprezentantów omawianej formy, korzysta niekiedy z tzu. leitmotivu ${ }^{32}$, czyli fragmentu muzycznego pojawiającego się wielokrotnie w trakcie trwania jednego spektaklu radiowego, którego zadaniem jest przywoływanie określonego zjawiska, stanu, osoby lub tworzenie pauzy $\mathrm{w}$ fabule. Jako przykład podam tutaj fragment I will always love you Whitney Houston w słuchowisku Muzyczka ${ }^{33}$.

\section{Spojrzenie na muzykę w słuchowisku oczami prakłyka}

W tej części testu odwołuję się do tez pochodzących z wykładu Małaszko-Stasiewicz ${ }^{34}$ poświęconego funkcjom muzyki i sposobom jej używania w słuchowiskach i reportażach. Przytoczone zestawienie stanowi próbę ich nazwania i usystematyzowania. Zatem zdaniem autorki wykładu możliwe są następujące funkcje muzyki:

- historyczna - motywy czy też całe utwory muzyczne, przywołujące konkretne czasy lub wydarzenia historyczne, na przykład totalitaryzm, holocaust, komunizm;

- scenograficzna - muzyka stanowi element przeniesienia słuchacza na jakiś określony obszar geograficzny, w jakieś miejsce, las, miasto, dom; „stworzenie landschaftu";

- $\quad$ kontrastująca - użycie muzyki na zasadzie kontry do treści, przełamywanie najbardziej dramatycznych treści zabawnymi, komediouymi ustawkami muzycznymi;

- komentatorska - użycie muzyki jako pewnego rodzaju odautorskiego komentarza, pokazanie swojego głosu w słuchowisku;

- scalająca - w tym przypadku sceny jako łącznika, ale nie bez znaczenia, nadanie nowego sensu konkretnym scenom;

- nawiązująca - nawiązywanie muzyką do stanu umysłu bohatera, uczuć mówiącego, truająca pewna niezmienna wartość niezależnie od zmiennego czasu.

31 Termin stosowany u filmoznawstuie. Zob. J. Płażeuski, op. cit., s. 344-350.

32 E. Pleszkun-Olejniczakowa, Jak jest zrobione stuchowisko? O morfologii $i$ znaczeniu, o kreacji i znaku [w:] E. Pleszkun-Olejniczakowa, J. Bachura, A. Pawlik, op. cit., s. 110.

${ }^{33}$ Muzyczka, reż. W. Modestowicz.

34 Małgorzata Małaszko-Stasiewicz - muzykolog, autorka opracowań muzycznych najpierw w teatrze tradycyjnym, później w Teatrze Polskiego Radia, laureatka wielu prestiżouych nagród w tej dziedzinie, opracowywała zarówno słuchowiska, jak i reportaże radiowe, uspółpracuje ze Studiem Reportażu i Dokumentu; w 2007 roku została wicedyrektorem ds. muzycznych, a obecnie pełni funkcję dyrektora Programu Drugiego Polskiego Radia. W 2014 roku znalazła się wśród nominowanych do nagrody „Niptel” za „niezmienne utrzymywanie poziomu i kulturotwórczego charakteru Programu 2 PR". W 2011 roku odznaczona przez prezydenta RP Bronisława Komorouskiego Srebrnym Krzyżem Zasługi. 
O walorach edukacyjnych wykładu Małaszko-Stasiewicz może świadczyć fakt, że udzieliła ona także wielu rad potencjalnym twórcom sztuki radiowej choćby w kwestii czysto technicznego użycia muzyki. Jak mówiła bowiem: „można szatkować, ciąć fragmenty, ale znaczące jest także, kiedy ta muzyka się skończy, nie można sobie tak po prostu u dowolnym momencie ładnie uyciszyć, żeby dźwięk się guałtownie nie skończył, nie o to chodzi". Widać więc, jak ważna jest świadomość użycia muzyki, ale także, co Małaszko-Stasiewicz szczególnie podkreślała, bodaj ważniejsza jest świadomość jej nieużywania. Idzie tu nie tylko o nieułaściwe użycie muzyki, będącej jedynie przeryunikiem, co jest niedopuszczalne, ale także o celowe zastosowanie ciszy, w niektórych przypadkach dużo bardziej wymownej niż muzyka.

Ponadto uskazywała na myślenie o efektach naszych działań przy używaniu muzyki, na zastanawianie się i odpowiadanie sobie na pytanie „co wnosi dany fragment”, a coś unosi zausze, to pewne. Wielokrotnie podkreślała, że „muzyka musi być nośnikiem treści”, a „każdy pojawiający się dźwięk musi mieć znaczenie”. Z tym łączy się ściśle odpowiedzialność twórców za swoich słuchaczy, odpowiedzialność reżysera i realizatora, rzetelność osoby sprawującej pieczę nad muzyką słuchowiska: „to autor odpowiada za uywołanie emocji u słuchaczu", przy czym zaznacza też, co cenne, że „nie może to być jeden rodzaj emocji u obrębie jednego utworu”.

W zakresie samej kompozycji i charakteru utworu istotna, aczkolwiek wzbudzająca wiele kontrowersji, była konstatacja na temat funkcji manipulacyjnej muzyki i dość pejoratywne odniesienie do „rzewnych melodyjek Disneya” czy też „Hollywoodzkich filmów dostających Oscara". Czy zatem użycia takiej muzyki autor oprawy muzycznej winien się wystrzegać? To pytanie pozostało bez jednoznacznej odpowiedzi, jednak w istocie wydaje się, że powinno ono pozostać pytaniem retorycznym. Ostatecznie zatem trudno jest rozstrzygnąć, gdzie leży granica upływania muzyką na odbiorcę, granica „rzewności” i „nierzewności” melodii.

Nawiązując do klarownego przekazu, który autor chce osiągnąć, Małaszko-Stasiewicz mówiła: „ja zausze stanę po stronie prostoty, nie ma co kombinować z umieszczaniem muzyki, która zakłócałaby tok narracji”; tok narracji właśnie pełni, jej zdaniem, funkcję nadrzędną wobec muzyki. W dalszej części wykładu przestrzegała przed swoistą tautologią: , ,nie ma niczego gorszego, niż dopowiadanie muzyką tego, co już jest powiedziane słowem, nie ma też potrzeby podkreślać oczywistego". W walce zaś o uwagę słuchaczy zalecała kontrastowanie - „by zrobić rozzieu pomiędzy światami, treściami, dajemy coś bardzo nieoczywistego". Stawiała na różnicowanie odniesień: „nie musi być tak, że historia jest z 1939 roku i melodia też z 1939, możemy łączyć uspółczesność z barokiem, myśląc o tym, co dźwięk niesie, jaki ma przekaz". Podsumourując swój wywód, Małaszko-Stasiewicz przypomniała dwie, jej zdaniem, podstawowe kwestie: myślenie i bunt, jako dwa cele, lecz również dwa sposoby na dotarcie do słuchacza. Ta druga, tj. bunt, może być osiągana nie tylko przez warstuę semantyczną, ale także przez prowokowanie na zasadzie: „coś mi się tutaj nie podoba, ta muzyka tutaj nie pasuje", zatem przez pobudzanie pamięci, prowokowanie wewnętrznej 
dyskusji czy próbę dotarcia do podświadomości. Ostatnie zdanie uykładu: „jeśli mówimy o sztuce: nic tak nie zabija sztuki jak schematyzm", zdaje się kierować twórców nie tyle ku zasadom, ile ku świeżości, kreatyuności, chęciom do działania.

\section{Artysta-muzyk a muzyka w słuchowisku}

Skoro punkt widzenia duu pierwszych grup został już zaprezentowany, należy teraz, jak sądzę, zająć się muzykami, którzy może nie są najmniej liczni, ale chyba najmniej widoczni. Po pierwsze dlatego, że większą uwagę przywiązuje się do reżysera czy odtwórców głównych ról niż do muzyków biorących udział w słuchowisku. Grupę tę także można analizować dwojako. W pierwszym przypadku jako artystów-współtwórców słuchowisk, w drugim artystów-odbiorców. Muzyka zapewne jest ważna dla każdej z tych grup, pozwolę więc sobie spojrzeć z obu perspektyw. Tutaj znów wkrada się teoria, przy czym jest to wiedza zaczerpnięta z historii muzyki klasycznej - bliskiej instrumentalistom czy wokalistom.

Biorąc pod uwagę aspekt interpretacyjny słuchowisk, uważam za słuszny podział muzyki Zofii Lissy na muzykę programową i absolutną, który to właśnie został zapożyczony przez badaczkę z historii i teorii muzyki klasycznej.

Muzyka programowa swoją warstwą foniczną ilustruje jakieś zjawisko rzeczywiste (szum morza, odgłosy pracy jakiejś maszyny itp.) $)^{35}$, zatem nie jest asemantyczna.

W muzyce programowej wykorzystuje się różne źródła treści pozamuzycznych: literackie, malarskie, filozoficzne, historyczne, autobiograficzne, przyrodnicze. Natomiast do zewnętrznych jej przejawów należą: tytuł utworu, tytuły części w przypadku utworów cyklicznych, czasami ustęp lub komentarz literacki, ureszcie same motywy i ogólny charakter utworu ${ }^{36}$.

Po tym wyjaśnieniu oczywistą rzeczą jest istota użycia muzyki w słuchowiskach. Odbiorcy w okamgnieniu, dzięki swojej wiedzy, preferencjom muzycznym czy niejednokrotnie instynktownie rozpoznają przynależność utworu do określonych wyobrażeń pozamuzycznych i takie same zastosują. Za pewnik mogę przyjąć skojarzenia z muzyką indiańską i afro-amerykańską słuchaczy po użyciu u słuchowisku IX symfonii $Z$ nowego świata ${ }^{37}$ Antonina Dvoraka, gdyż te upływy są u niego bardzo silnie zarysowane. Podobnie rzecz miałaby się choćby z suitą programową Peer Gynt Edwarda Griega i utworem $W$ grocie króla gór ${ }^{38}$. Śmiem wątpić, czy użycie tych utworów u celu pokazania sielanki na wiejskim podwórku byłoby zasadne. Pozostając więc daleko od krytykanctua, pragnę tylko zasygnalizować istotę rzeczy, ważność doboru muzyki i świadomości jej używania. Muzyka programowa może być fantastycznym

\footnotetext{
35 Z. Lissa, Czy muzyka jest sztuka asemantyczną?, „Myśl Współczesna” 1948, nr 10, s. 277.

36 M. Kowalska, ABC historii muzyki, Musica Iagellonica, Kraków 2001, s. 458.

37 https://wuw.youtube.com/watch?v=WuqyfEyNXQo [dostęp: 30.03.2015].

38 https://www.youtube.com/watch?v=oUL4qtQIEQY [dostęp: 30.03.2015].
} 
środkiem przekazu myśli i estetyki dzieła, jeśli oprawca muzyczny, jak nazywają sami siebie autorzy oprawy muzycznej słuchowisk, liczy się z konsekwencjami posługiwania się nią.

Przeciwieństuem muzyki programowej jest muzyka absolutna, „wyrażająca zjawiska psychiczne, ale nie na zasadzie reprezentacji wprost, ale na prawidłach symbolicznych"39. Motywy muzyczne w tym przypadku nie narzucają tak oczywistych skojarzeń, dlatego ich umieszczenie w słuchowisku może być mniej ryzykoune niż w pieruszym przypadku. Różnice między pieruszym a drugim typem tak ujęła sama Lissa:

w muzyce absolutnej struktury dźwiękowe ujawniają słuchaczom jakieś najbardziej ogólne typy jakości uczuciouych [radość, smutek - P.W.], w muzyce programowej skierouują intencję słuchaczy w pewnych tylko momentach na konkretne przebiegi przedstawione, a poprzez nie dopiero ku jakościom emocjonalnym ${ }^{40}$.

Obie formy muzyki mogą uspółistnieć w obrębie jednego dzieła radiowego, jeśli jest to zasadne i zaplanowane przez nadawców, ponieważ muzyka, jak zaznacza Elżbieta Pleszkun-Olejniczakowa, w każdym gatunku artystycznym tekstu audialnego „wywiera potężny upływ na psychikę odbiorcy” ${ }^{41}$.

Odpowiednie zilustrowanie muzyczne łączy się ściśle z osobami kompozytora i ilustratora muzycznego, chociaż biorąc pod uwagę częstotliwość ich udziału w słuchowiskach kolejność winna być odurotna, niestety choćby z powodów finansouych nie sposób zatrudniać osoby piszące muzykę oryginalną tak często. Słuchowisk z dobraną i opracowaną muzyką jest o wiele więcej, niż tych z celowo napisaną ścieżką służącą konkretnemu przedstawieniu radiowemu. I to się jednak powoli zmienia, bowiem jak zauważa Andrzej Brzoska, uybitny realizator dźwięku:

Obecnie jest więcej słuchowisk z muzyką oryginalną niż w latach ubiegłych. Udało się pozyskać kilku utalentowanych kompozytorów, którzy zechcieli specjalnie dla słuchowisk napisać muzykę. To bardzo ważny element radiowego teatru, niezmiernie podnoszący jego wartość ${ }^{42}$.

Na szczególną uwagę wśród słuchowisk z oryginalnie napisaną doń muzyką należą: Novecento ${ }^{43}$, Aniołów czas ${ }^{44}$ nagrodzone w 2014 roku na Festiwalu Teatru

39 K. Klimczak, P. Czarnek, op. cit.

40 Z. Lissa, Muzyka i film. Studium pogranicza ontologii, estetyki i psychologii muzyki filmowej [w:] Z. Lissa, Wybór pism estetycznych, uprowadzenie, uybór i oprac. Z. Skowron, Towarzystuo Autorów i Wydawców Prac Naukouych Universitas, Kraków 2008, s. 242.

41 E. Pleszkun-Olejniczakowa, Demiurg czy Cicerone?, O sposobach istnienia stowa i tekstu audialnego na antenie [w:] Słowo w kulturze wspótczesnej, red. W. Kawecki, K. Flader, Wydawnictwo Uniwersytetu Kardynała Stefana Wyszyńskiego, Warszawa 2009, s. 264.

42 J. Bachura, Odsłony wyobraźni: wspótczesne stuchowisko radiowe, Wydawnictwo Adam Marszałek, Toruń 2012, s. 343.

43 Novecento, reż. J. Zaorski, muz. W. Paulik.

44 Aniołów czas, reż. J. Kukuła, muz. R. Kulczycki. 
Polskiego Radia i Teatru Telewizji Polskiej „Dwa Teatry” słuchowisko Mistrz Manole $^{45}$.

Do pierwszego z nich muzykę skomponował Włodek Pawlik, znany i ceniony pianista - jazzman, jedyny w historii muzyki polskiej laureat prestiżowej nagrody Grammy. Wybór tego artysty jest, jak przypuszczam, nieprzypadkowy, ponieważ fabuła słuchowiska również traktuje o utalentowanym muzyku. Zatem historia niejako zatoczyła koło, pozwalając słuchaczowi na odkrycie dodatkowego znaczenia w całym, komplementarnym dziele radiowym, którym jest Novecento. Dla autora muzyki natomiast była to niepoutarzalna szansa odkrycia siebie na nowo, próba zderzenia się z własnym doświadczeniem jako muzyka, a także możliwość oddania prawdziwych emocji, co dla tego rodzaju sztuki szczególnie ważne.

Słuchowisko wyreżyserował Janusz Zaorski na podstawie sztuki włoskiego autora Alessandro Baricco. Historię głównego bohatera opowiada jego przyjaciel ze statku Virginian - trębacz Tooney. To on, uprowadzając retrospekcję, uspomina znalezienie noworodka w kartonie po cytrynach 1 stycznia 1900 roku przez starszego już marynarza - Danny'ego Boodmana. Mężczyzna stał się przybranym ojcem dla maleńkiego chłopca, którego na pamiątkę dnia i okoliczności jego odnalezienia nazwał Danny Boodman T.D. Lemon Novecento. Dla świata chłopiec właściwie nie istniał. Nie miał domu, metryki, daty urodzenia ani nazwiska, więc gdy jego opiekun zmarł, ośmioletni wówczas Novecento zniknął na kilka dni, nie pokazując się nikomu, w obawie przed zesłaniem na ląd. Objawił się pewnej nocy wraz ze suoim ogromnym talentem, grając na fortepianie w ciemnej sali, wzruszając przy tym słuchaczy z pieruszej klasy. Kolejny koncert, który możemy usłyszeć w uykonaniu głównego bohatera, przypada na rok 1927, kiedy to na statek wchodzi jego późniejszy przyjaciel Tooney. Zarówno Novecento, jak i towarzyszący mu trębacz zapowiadani są odbiorcy fragmentem muzycznym granym na fortepianie lub trąbce. Pozwala to na jasne oddzielenie postaci, jak również ich charakterystykę przez instrument, na którym grają. Ich pierwsze spotkanie odbyło się przy wtórze szumu fal i wiatru w sztormowy wieczór. Wtedy właśnie Novecento zagrał przepięknego walca, który idealnie komponował się z ruchami statku i dźwiękami skrzypiącej drewnianej podłogi. Jest to chyba najbardziej magiczny moment u całym słuchowisku. Delikatna linia melodyczna u górnej partii fortepianu, przywołująca w okamgnieniu rejs na morzu przed oczy słuchacza, nie pozwala na opisanie jej, oddającymi jednocześnie kunszt i prostotę, słowami. W toku fabuły dzieła udowadnia zasłużony przydomek pianisty - „największy na oceanie”. Biorąc zaś pod uwagę słuchowisko w całej postaci, potwierdza trafny wybór reżysera uzględem kompozytora muzyki, która w niewielkiej części była zapisana, bowiem w większości stanowiła rejestrację swobodnych improwizacji Pawlika i jego reakcji na obrazowe wskazówki reżysera. Moim zdaniem kompozytor i wykonawca w jednym, który dodatkowo może ingerować w melodię i reagować na zmiany reżysera tu i teraz to

${ }^{45}$ Mistrz Manole, reż. D. Błaszczyk, muz. J. Hałas. 
prawdziuy skarb. Współpraca tego rodzaju musi przynieść owocne efekty, czego dowodem jest niewątpliwie Novecento.

W podobny sposób - inspirująco i rozwijająco - może stymulować wysłuchanie kilku innych słuchowisk z dobrą muzyką, jak choćby Moja Abba ${ }^{46}$, Solo na trąbkę lub Obłoczni, czyli sen Chopina ${ }^{48}$. Zatem istotna jest celowość poustawania słuchowisk o muzyce oraz tych, które obfitują w muzykę na dobrym poziomie. Zauważyć można, że preteksty do uykreowania fabuły i stworzenia całego słuchowiska są zgoła różne. W jednym przypadku jest to miłość do instrumentu, u kolejnym sama muzyka, dalej relacja między muzykami czy ureszcie chęć osiągnięcia sukcesu. Odmienne będą także odczucia słuchaczy po seansach audialnych. I tak od prozaicznych pobudek, dla których sięgamy po formę słuchowiska i dla których są one proponowane odbiorcom, jak rozrywka czy chęć oderwania się od codzienności, aż do poważnych jak choćby przemyślenie określonego problemu czy nawet przeżycie swego rodzaju katharsis.

Dla przykładu przywołam tutaj główną bohaterkę słuchowiska Moja Abba. Po przemyśleniu jej przygody możemy dojść do uniosku, że my także mamy suoje ideały i pasje, że nie powinniśmy bać się inwestowania u siebie, że może warto otworzyć się na drugiego człowieka i nie żyć wyłącznie uspomnieniami, gdyż może nas jeszcze spotkać coś dobrego w życiu. Kolejnym tego typu bohaterem może być trębacz - amator ze słuchowiska Solo na trąbkę. Dzięki niemu słuchacz może uświadomić sobie, co ma najwyższą wartość, a czego nie dostaje się dwa razy. Każde słuchowisko kryje w sobie pewną metaforę. W jego bohaterach każdy może odnaleźć siebie i dzięki temu postąpić lepiej, uybaczyć samemu sobie lub docenić to, co ma. W pewnych kręgach, na przykład muzyków, wysłuchanie takiej audycji może być też wielką inspiracją lub motywacją. Wspomnieć tu należy o Obłocznych w reżyserii Grzegorza Walczaka, gdzie wykonywana $w$ niekonwencjonalny sposób muzyka Chopina może obudzić w kimś chęć zaaranżowania czy też zaadaptowania na inne instrumenty mazurków, nokturnów czy preludiów.

Autorka opracowań muzyki Chopina u tym słuchowisku, Maria Pomianouska, wystylizowała utwory na tyle, że w pewnych momentach ich rozpoznanie może być utrudnione. Na płycie Chopin na pięciu kontynentach Pomianowska wspaniale eksperymentuje z muzyką klasyczną. Przekłada ją na język estetyki orientalnej, afrykańskiej czy rytmów kubańskich. Parafrazuje znane utwory, by przenieść słuchacza w jednej chwili na inny kontynent. Pokazuje duży kontrast pomiędzy muzyką Chopina, którą znamy, a tą, którą sama proponuje. Używa do tego rozmaitych środków w postaci egzotycznych instrumentów, takich jak: sitar, salangi, kamancza gadułka, szałamaja, harmonia deptana, lira korbowa, cymbały. Dla muzyka otwiera to różnorodność doświadczeń: poznawanie nowych stylów wykonawczych, instrumentów, nieznanych dotąd sposobów uydobywania dźwięku. Dzieje się tak nie tylko w zakresie

46 Moja Abba, reż. T. Man, muz. duet Karbido.

47 Solo na trąbkę, reż. J. Kukuła, muz. E. Pałłasz.

48 Obłoczni czyli sen Chopina, reż. W. Modestowicz, muz. M. Pomianouska. 
używania możliwości instrumentów, ale także głosu, jak w przypadku Mistrza Manole.

Rodzajem motywacji i wzorami do naśladowania mogą być saksofoniści ze słuchowisk Andrzeja Piszczatouskiego. Idąc za ich przykładem, można ćuicząc jeszcze więcej zbudować uspaniałą relację z instrumentem i dzięki temu stać się lepszym muzykiem. Ostatnim już, będącym nieco na uboczu, celem, może być propagowanie ambitnej muzyki, do której już poza ramami słuchowiska będzie można sięgnąć, gdy zapisze się w pamięci.

Co godne zauważenia, nagrodzone i docenione słuchowiska o muzyce nie są pomysłami reżyserów-muzyków. Widać więc, że muzyka dotyczy mniej lub bardziej każdego z nas i każdy z nas ma potrzebę jej uyrażenia, ukazania jej piękna i niepoutarzalności. Także reżyserzy czują, że historie muzyczne, kulisy życia z muzyką na co dzień, są warte opowiedzenia. Odbiorcy natomiast potrzebują po prostu dobrej fabuły opatrzonej odpowiednią muzyką. Wszystkie te czynniki, uspółpraca między twórcami, odbiorcami, muzykami a teoretykami, pozwalają na ciągły rozwój tego tematu, na poszukiwania i innowacje, a także na uporządkowanie wiedzy dla przyszłych pokoleń i ocalenie od zapomnienia artystycznych dzieł audialnych - ze słuchowiskami na czele.

\section{Podsumowanie}

W 1938 roku amerykańska stacja CBS wyemitowała słuchowisko Orsona Wellesa Wojna światów ${ }^{49}$. Nigdy wcześniej sztuka radiowa nie miała tak ogromnej mocy i prawdopodobnie nigdy już mieć nie będzie. Świat wykreowany w tym słuchowisku był tak autentyczny, że setki ludzi uwierzyły w wizytę nieproszonych gości, czyli Marsjan, na Ziemi. Współcześni twórcy z pewnością mają świadomość tego, że stworzenie dziś róunie spektakularnej audycji nie jest możliwe. Jasnym jest jednak, że każda forma twórczości radiowej zostawia ślad w odbiorcy, a szczególną formą zapisywania się u pamięci słuchaczy jest właśnie słuchowisko. Jego związki z literaturą: ciągi przyczynowo-skutkowe, bohaterowie, czas i miejsce akcji oraz nierzadko metaforyczny język, w połączeniu z niebagatelną rolą muzyki tworzą szeroką mapę odniesień, oddzielny kontekst, który zapisuje się w pamięci. Owe skojarzenia są budowane także przez dwie zasadnicze funkcje słuchowiska: edukacyjną i rozrywkową. Dzięki treściom, które bawią słuchacza i tym, które uczą, będąc pewnym novum, nieznanym dotąd faktem, szanse na powtórne przez niego sięgnięcie do konkretnego dzieła audialnego lub do kolejnych przedstawicieli tego gatunku są naprawdę duże.

Co zaś dotyczy muzyki, prozaiczną jej funkcją jest odświeżanie uwagi odbiorcy, gdy ten może być już nieco znudzony jedynie słowem. Ważniejszymi jednak są: ogromna rola w budowaniu dramaturgii i kreowaniu postaci, ułatwienie zrozumienia

${ }^{49}$ Wojna światów, reż. O. Welles. 
pewnych kwestii, skierowanie wyobraźni w konkretne miejsce czy kontekst. Muzykę względem pełnionej przez nią funkcji określa się mianem ilustracyjnej, scenograficznej, komentatorskiej, scalającej czy nawiązującej. Pewne jest, że zawsze u połączeniu ze słowem niesie ona ze sobą pewną treść, czego należy być świadomym. Niejednokrotnie wiedza na ten temat decyduje o sukcesie bądź porażce słuchowiska.

Reasumując, pragnę podkreślić znaczenie pracy dla mnie samej. Muzyka jest dla mnie ważna od zausze, podobnie istotna jest dla słuchowiska, natomiast od teraz obie dziedziny istnieją u moim pojmowaniu nierozerwalnie. Ta krótka rozprawa była zarówno powodem, jak i celem, zuieńczeniem, ale także początkiem fascynacji. Dzięki niej bardzo wiele się nauczyłam, sięgnęłam do ciekawej literatury, rozwinęłam swoje zdolności interpretacyjne i badawcze. Poznane publikacje i słuchowiska wzbudziły moją ciekawość i stały się twórczą inspiracją. Obowiązek okazał się przyjemnością, jaką, mam nadzieję, było również przeczytanie tej pracy.

\section{Bibliografia}

Albińska K., Jaskótka zwiastująca wiosnę czy relikt przeszłości? Z badań nad atrakcyjnościa stuchowiska radiowego, „Acta Universitatis Lodziensis. Folia Litteraria Polonica” 2011, t. 14.

Aniołów czas, reżyseria Janusz Kukuła, muzyka Rafał Kulczycki.

Bachura-Wojtasik J., Odstony wyobraźni: wspótczesne stuchowisko radiowe, Wydaunictwo Adam Marszałek, Toruń 2012.

Bachura-Wojtasik J., Analiza semiologiczna wspótczesnego słuchowiska, „Acta Universitatis Lodziensis. Folia Litteraria Polonica" 2010, t. 13.

Bachura J., Pawlik A., Stuchowisko i jego „anatomia” [w:] E. Pleszkun-Olejniczakowa, J. Bachura, A. Pawlik, Dwa Teatry. Studia z zakresu teorii i interpretacji sztuki stuchowiskowej, Wydaunictuo Adam Marszałek, Toruń 2011.

Bachura-Wojtasik J., Pawlik A., Znaczeniowa funkcja muzyki w stuchowisku, „Acta Uniwersitatis Lodziensis. Folia Literraria Polnica” 2012, nr 3.

Bardijewska S., Nagie stowo. Rzecz o stuchowisku, Dom Wydawniczy Elipsa, Warszawa 2001. Czarnek P., Klimczak K., Rola muzyki we wspótczesnym reportażu radiowym, „Acta Universitatis Lodziensis. Folia Literraria Polonica" 2012, t. 17, nr 3.

Drygas M., Wyzwolić wyobraźnię, dokument radiowy [w:] Biblia dziennikarstwa, red. A. Skwosz, A. Niziołek, Społeczny Instytut Wydauniczy Znak, Kraków 2010.

http://pl.wikipedia.org/wiki/Dwa_Teatry [dostęp: 31.03.2015].

http://pl.wikipedia.org/wiki/W\%C5\%82odzimierz_Pawlik [dostęp: 23.03.2015].

http://www.dwateatry.tvp.pl/ [dostęp: 01.04.2015].

http://uww.polskieradio.pl/9/333/Artykul/480616,Scena-Teatralna-Trojki-prezentuje-Moja-ABBA [dostęp: 24.03.2015].

http://www.wirtualnemedia.pl/artykul/malaszko-stasiewicz-dwojki-sluchaja-mlodzi-jak-i-starsi\# [dostęp: 22.03.2015].

https://www.youtube.com/watch?v=oUL4qtQIEQY [dostęp: 30.03.2015].

https:/www.youtube.com/watch?v=W6qDZr3hmXA [dostęp: 24.03.2015]. 
https://wuw.youtube.com/watch?v=WuqyfEyNXQo [dostęp: 30.03.2015].

Kaziów M., O dziele radiowym - z zagadnień estetyki oryginalnego słuchowiska, Zakład

Narodowy im. Ossolińskich, Wrocław 1973.

Kowalska M., ABC historii muzyki, Musica Iagellonica, Kraków 2001.

Kuiatkouski T., Muzyka w literaturze wspótczesnej, „Ruch Muzyczny” 1948, nr 8.

Lissa Z., Czy muzyka jest sztuką asemantyczną?, „Myśl Współczesna” 1948, nr 10.

Lissa Z., Muzyka i film. Studium pogranicza ontologii, estetyki i psychologii muzyki filmowej

[w:] Z. Lissa, Wybór pism estetycznych, wprow., wybór i oprac. Z. Skowron, Towarzystwo

Autorów i Wydawców Prac Naukowych Universitas, Kraków 2008.

McLuhan M., Zrozumieć media. Przedłużenia człowieka, tłum. N. Szczucka, Wydawnictua

Naukowo-Techniczne, Warszawa 2004.

Mistrz Manole, reżyseria Dariusz Błaszczyk, muzyka Jacek Hałas.

Moja Abba, reżyseria Tomasz Man, muzyka duet Karbido.

Muzyczka, reżyseria Waldemar Modestowicz.

Myśliuski W., Traktat o łuskaniu fasoli, Społeczny Instytut Wydawniczy Znak, Kraków 2007.

Novecento, reżyseria Janusz Zaorski, muzyka Włodek Paulik.

Obłoczni czyli sen Chopina, reżyseria Waldemar Modestowicz, muzyka Maria Pomianouska.

Ong W.J., Oralność i piśmienność. Słowo poddane technologii, tłum., ustęp i red. nauk. J. Japola, wyd. 2 popr., Wydawnictua Uniwersytetu Warszauskiego, Warszawa 2011.

Pisarek W., Stownik terminologii medialnej, Touarzystwo Autorów i Wydawców Prac Naukouych Universitas, Kraków 2006.

Pleszkun-Olejniczakowa E., Demiurg czy Cicerone?, O sposobach istnienia słowa i tekstu audialnego na antenie [w:] Stowo w kulturze wspótczesnej, red. W. Kawecki, K. Flader, Wydawnictuo Uniwersytetu Kardynała Stefana Wyszyńskiego, Warszawa 2009.

Pleszkun-Olejniczakowa E., Jak jest zrobione stuchowisko? O morfologii i znaczeniu, o kreacji i znaku [w:] E. Pleszkun-Olejniczakowa, J. Bachura, A. Pawlik, Dwa teatry. Studia z zakresu teorii i interpretacji sztuki stuchowiskowej, Wydawnictwo Adam Marszałek, Toruń 2011.

Pleszkun-Olejniczakowa E., Bachura J., Pawlik A., Dwa Teatry. Studia z zakresu teorii i interpretacji sztuki stuchowiskowej, Wydawnictwo Adam Marszałek, Toruń 2011.

Płażeuski J., Język filmu, Książka i Wiedza, Warszawa 2008.

Saksofon basowy, reżyseria Andrzej Piszczatouski, muzyka Małgorzata Małaszko-Stasieuicz.

Solo na trąbkę, reżyseria Janusz Kukuła, muzyka Edward Pałłasz.

Trzy poetyki klasyczne: Arystoteles, Horacy, Pseudo-Longinos, tłum. T. Sinko, Zakład Narodowy im. Ossolińskich, Wrocław 1951.

Tuszewski J., Paradoks o stowie i dźwięku. Rozważania o sztuce radiowej, Wydawnictwo Adam Marszałek, Toruń 2002.

Wojna światów, reżyseria Orson Welles.

Wybierz saksofon, reżyseria Andrzej Piszczatouski, muzyka Małgorzata Małaszko-Stasiewicz.

Zgółkowa H., Praktyczny słownik wspótczesnej polszczyzny, t. 1, Wydawnictuo Kurpisz,

Poznań 1994. 